\title{
Why Do People Move to Cohousing Communities in Sweden? - Are there any Significant Differences Between the +40 Cohousing and the Mixed-Age Cohousing?
}

\author{
Jung Shin Choi \\ Professor, Department of Consumer and Housing Studies, The Catholic University of Korea, Seoul Korea
}

http://dx.doi.org/10.5659/AIKAR.2013.15.2.77

\begin{abstract}
Cohousing is based on collaborative network, or fictive kin in the community. It could facilitate the goal of self-sufficiency. This research aims to investigate the motivation of move to cohousing communities in Sweden, and to find out if there are any significant differences according to two different cohousing types; between the +40 cohousing and the mixed-age cohousing. The +40 cohousing is a kind of senior cohousing in which residents are supposed to be aged over 40. Questionnaire survey was applied and 242 collected data were analyzed by SPSS statistical program.

Notable differences in demographic and dwelling variables are found between the 2 groups. There are more women, singles, academics, and small dwellings in the +40 cohousing than in the mixed-age cohousing. Referring motivation of move, "sharing common activity" and "idea of cohousing" are commonly noticed as the main reasons why people move to cohousing communities. Major difference between the 2 groups is that residents of the +40 cohousing tend to stress more on social interaction with neighbors than practical merit. On the contrary, ones of the mixed-age cohousing focus more on practical advantage than social interaction. As a conclusion, it is evident that motivation of move to cohousing communities is different by cohousing types, which have different residents' characteristics.

Cohousing could contribute to elevate marginal group's quality of life as an alternative living environment. Therefore, cohousing design has to be tailored to adapt residents' specific needs of different life-stages. In order to implement cohousing model into other countries, for instance into Korea, it needs to experiment with the notion of transplanting selected cohousing principles to a public housing development. In the mixed-age cohousing where more dual income families with young children than conventional housing developments reside, residents would need more practical advantage than emotional support in the community, while as residents in the senior cohousing need vice versa.
\end{abstract}

Keywords: Cohousing, Sweden, Motivation of Move, Senior Cohousing, +40 Cohousing, Mixed-Age Cohousing.

\section{INTRODUCTION}

\subsection{Background of the study}

Cohousing is a form of intentional community that has started in Scandinavian countries where typical nuclear family structure changed rapidly compared to other countries. Intentional community is a settlement that a group of people with same idea has established intentionally to form a more humane living environment. Cohousing communities are neighborhood

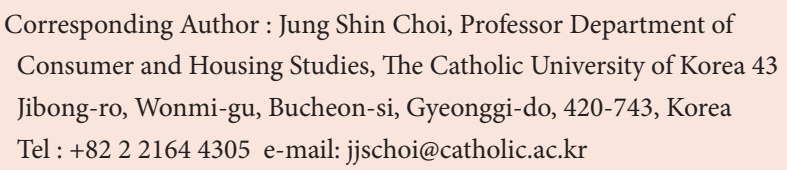

This paper was supported by research fund of the Catholic University of Korea 2011.

This is an Open Access article distributed under the terms of the Creative Commons Attribution Non-Commercial License (http://creativecommons. org/licenses/by-nc/3.0/) which permits unrestricted non-commercial use, distribution, and reproduction in any medium, provided the original work is properly cited. developments that creatively mix private dwellings and common facilities to recreate a sense of community, while preserving a high degree of individual privacy. In cohousing community, residents actively participate in the design and operation of daily living. Cohousing encourages shared living, sees members, jointly build and develop urban housing projects. Through an emphasis on traffic-free development and reference to strong community sentiment, cohousing is construed by parents as providing a safer and more desirable location for raising children (Tchoukaleyska, 2011). Cohousing is also considered as a desirable living arrangement for elders from the perspective of secure housing environment, mutual support amongst residents, making use of human resources after retirement and decrease of loneliness (Choi \& Paulsson, 2006; Glass, 2009).Cohousing goes beyond theory as the phenomenon that started in Scandinavia 30 years ago is now spreading in the Anglo-Saxon world since the 1990s, and more recently in the rest of Europe and in Japan (Lietaert, 2010). There are various examples of cohousing communities fitted to each country's situation. Sweden is one of the most noted countries, which has higher proportion of married women at the labor market, and also of older people over 65 among whole population than other countries. These social situations might have influenced 
to development of cohousing in Sweden. Two different types of cohousing have been evolved in Sweden in context of residents' age group; the +40 cohousing and the mixed-age cohousing.

However, there is little research concerning motivation of move to cohousing community so far. Why do people choose cohousing for their living?

The purpose of this research is to identify the reason why people move to cohousing communities in Sweden, and to find out if there is any significant difference according to the cohousing types; between the +40 cohousing and the mixed-age cohousing. This research could offer empirical information to form a cohousing community that is composed of different residents' characteristics. Residents' needs could be met more easily if you identify the reason why they choose to live in cohousing community.

Research questions are;

1) Are there any significant differences in residents' characteristics between the 2 cohousing types?

2) Do they have different motivation of move to cohousing communities between the 2 cohousing types?

3) Do variables of residents' characteristic affect motivation of move to cohousing communities?

\section{LITERATURE REVIEW}

\subsection{Cohousing Concept}

Ideology of cohousing is to promote residents' common activities in order to reduce daily chores as well as empowering social interaction amongst residents and security in the community. In modern society, people face to change of traditional family structure and higher proportion of married women in the labor market than before. These brought limit of time for daily chores and child rearing. Holistic emotional development for the only child and sense of belonging for single-person and elderly family are needed. As one of the solutions, cohousing is evolved to adjust merits of traditional extended family into modern society; mutual support, increase of intimacy with virtual kin, sense of belonging, and security in the community. These can be reached through participation in shared activities. Since a primary goal of cohousing is the desire of residents to live in a socially supportive setting, architectural design and site planning are among a number of means that, in combination with social organization factors, may serve to enhance or support the sense of community sought by residents (Marcus, 2000). Physical design of cohousing is quite different from the conventional housing development in context of architectural layout and size. Main components of cohousing development are communal space and individual dwellings placed intentionally to promote frequent meeting with inhabitants, while preserving privacy. Communal space occupy fairy ample in size, meanwhile individual dwelling is rather small compared to the conventional housing.

Classical cohousing developed in 1940s in Scandinavia by feminists' and modernists' movements aimed to reduce burden of daily chores for married working women in terms of gender equality (Vestbro, 1997). They expected paid working women could put more energy into labor market, if they rested at home as much as men did. It was a service-model in which paid staffs took care of house management, daily chores and even child rearing. Accordingly, though dwelling space was relatively small, rent was expensive. Eventually people began to criticize cohousing was a house only for the rich and elite group (Choi \& Paulsson, 2006). From the 1930s to the 1970s, 17 cohousing communities were built according to a model based on services through employed staffs. From the 1980s this model was replaced by modern cohousing called as self-work model, a model based on the residents' own work (www.kollecktivhus.nu). 50 self-work model cohousing units were built in the 1980s. Modern cohousing has merits from both social and practical advantages. Residents share daily chores on their own, aiming saving time and cost besides empowering social interaction with neighbors.

Equality between men and women has been a major aim of cohousing models. Common meals and other activities were designed to reduce housework in order to make women possible to combine gainful employment with family life. Toker (2010) found from the gender perspective that women in cohousing developments were engaged in less time for housework than ones in new urban developments in the US. In the last two decades, cohousing and new urban developments have emerged as alternative housing types in the US although cohousing still constituted a marginal portion of the housing stock. Findings indicated that cohousing developments attracted unconventional households and women with more egalitarian gender ideologies compared to new urban developments. Women living in cohousing developments spent a lower percentage of their time at housework and had more egalitarian gender ideologies compared to women living in new urban developments. The spatial organization within houses was also reflective of the differences between the two housing types.

Low-impact strategy is one of the core features of cohousing communities as well (Zhang, 2011). In order to reduce construction and living costs, most of cohousing reaches a consensus of resource sharing and energy saving on the common values of pro-environment and sustainability. Five dimensions as site planning and design, food consumption, trip mode, resource usage and energy system, enter into environmental strategies on ecological footprint in cohousing community. The endeavor of compact layout and building size cutback are direct ways to reduce footprint. Sharing common meals and resources, less driving and more recycling are proactive and effective environmental strategies by altering behaviors and life-style of cohousers; using renewable energy and energy-saving technologies to reduce energy consumption is an active approach conventionally applied in cohousing to reduce human ecological footprint (Yang, L. \& et als., 2010). In that respect, cohousing fits perfectly well with degrowth economic theories (Lietaert, 2010).

At the homepage of Färdknäppen cohousing in Stockholm, ecological practices in daily life of cohousing community are described as follows;

... We live in sustainable development. Our experience through living at Färdknäppen is that:

\section{${ }^{*}$ Environmentally}

-Less energy is needed and spent when people share amenities and services.

-Less waste of food when leftovers are taken care of.

- Less energy and packaging waste (paper, plastic, glass, metal) when dinner is made communally than if every single household 
makes food at home.

-Less paper waste when 43 households share newspaper subscriptions.

${ }^{\star}$ Economically

- When people share amenities and provide services and cultural activities for each other, it is easier for the individual to get by on a tight budget.

-Food is cheaper when an association can buy at wholesale prices.

- The society in general has lesser and fewer expenses for social services when elderly people are empowered and supported in their daily lives through a housing system such as Färdknäppen (cited from the Färdknäppen cohousing home page).

\subsection{The +40 Cohousing and the Mixed-age Cohousing in Sweden.}

Cohousing units in Sweden are found in major cities such as Stockholm, Göteborg and Lund-Malmö and a few other university cities (Figure1). 44 cohousing units are registered in the official homepage of Swedish cohousing communities www.kollektivhus. nu by the end of 2010 .

\section{Cohousing units in Sweden}

All but very few of the collective houses are found in the southern part of Sweden, mainly in the larger cities.

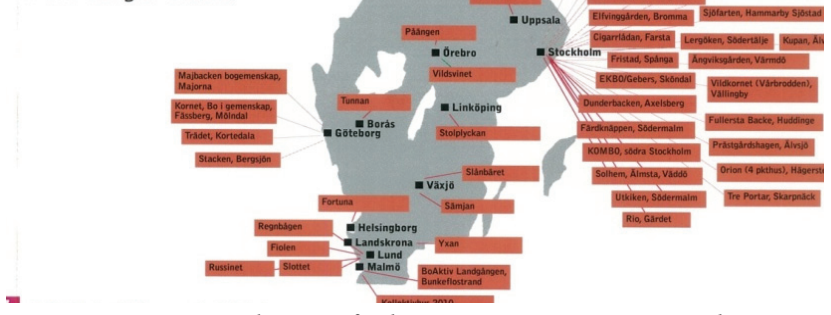

Figure 1. Distribution of cohousing communities in Sweden (Source : www.kollektivhus.nu)

The Swedish National Association "Kollektivhus NU" (Cohousing Now) is an association working to promote cohousing and other alternative ways of living. The association supports existing cohousing units as well as groups intending to create new units. Originally formed in 1981, it has recently been revitalized with the prime purpose to inform the public about cohousing as an alternative, and to influence authorities to facilitate the creation and running of such units. Over 40 cohousing units that exist in Sweden are mainly the result of civil society campaigns and positive responses from the public housing authorities during the 1980s. A vast majority of Swedes are unaware of alternatives such as cohousing and eco-villages etc., but today the positive trend is turning in favor of cohousing. Kollektivhus NU has an active collaboration with SABO -Swedish Association of Municipal Housing Companies - and its recent publication. It is increasingly consulted by politicians, housing companies and individuals (www. kollecktivhus.nu).

During the 1990s, a new cohousing form designed for the second half of life' was realized. This version was designed to serve the needs of people in the second half of life -40 years or older, with no children in the household. It attracts not least senior citizens who prefer a moderate level of collectivity. Of the 44 existing cohousing units, 8 belong to this category, and more are to come. Politicians see them as an answer to the 'aging' of the population and senior citizens' needs for togetherness and security (www.kollektivhus.nu). From the view point of age, the residents of the +40 cohousing are a group of the third age who are still healthy and active. That is the reason why they stress to be called as "the +40 cohousing" instead of "senior cohousing". On the other hand, for the mixed-age cohousing there is no age-limit for residents to move in so that diverse families can reside together. The +40 cohousing in Sweden, originally, stems senior cohousing/ +55 cohousing. Senior cohousing is a kind of ordinary housing development, not a service housing, which healthy residents choose and move in for their later life. Residents are expected to organize daily life by participating in shared activity. A senior cohousing resident is supposed to be a person who can choose one's living arrangement on his(her) own will before others choose the house after he(she) becomes too frail (Jensen,1994). In terms of age, a resident should be at least 55 years old or older to be subsidized for rental housing for the elderly by law in Denmark, or 50 years old or older in the Netherland. In Sweden, it had been as same as Denmark, but it changed into 40 years old or over instead of +55 cohousing (Choi \& Paulsson, 2011).

The goal of the +40 cohousing is to mix diverse age groups in a way even though it is not as much various as in the mixed-aged cohousing. In which, residents are mixed with ones who are still working in the society and ones who have already been retired. It is easier to support mutually amongst residents with different conditions. For instance, the younger who are still working can be supported by the retired, because pensioners have more extra time to take care of the house, and to input their human resources and experience to the community. The younger, in return, can bring fresh atmosphere from the outside world so that the +40 cohousing can be connected with conventional society. With this mean, they believe the +40 cohousing might be more sustainable than ordinary senior cohousing.
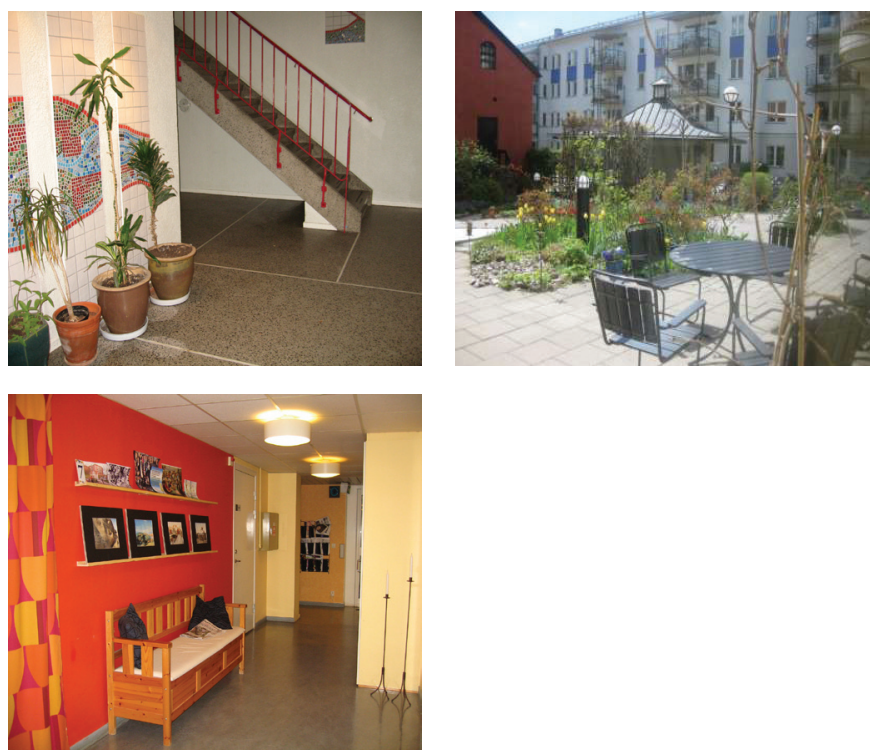

Figure 2. Swedish cohousing communities (Trädet : Mixed-age, Russinet and Majbacken : +40)

There have been many discussions about the subject which is better composition of cohousing residents in terms of age group in order to elevate resident's life satisfaction. Which is considered as better living arrangement for the third age between the +40 
cohousing and the mixed-age cohousing? According to previous researches, preference of residents' age group did not reveal so simple, for instance, people in senior cohousing preferred residents only seniors, while ones in the mixed-age cohousing did ageintegrated group. Research results meant that residents of the two different cohousing types have already moved to the place where they really preferred (Choi, 2006; Choi \& Cho, 2006; Choi \& Paulsson, 2006; 2011).

\subsection{Residential Mobility and Motivation of Move to Cohousing}

Residential mobility is a behavior to adjust housing space according to changing housing needs. It enables family to access housing service easier, which family members want to be supported. Some studies identified affecting factors to residential mobility as life-stage, quality of life, mobility behavior, housing characteristics, and satisfaction of neighborhood. Of those, lifestage was found as the most affecting factor (Choi et als, 1996; Choi \& Park, 1996). Yang \& Kim (2011) argued that changing preference of housing type by age, especially, was the main force of housing mobility. Duration of dwelling affected negatively to housing mobility, because of strong social cohesion with neighbors for long periods (Yang \& Kim, 2011). It was also found that housing size increased after residential mobility, showing that most moves were due to the deficit of housing space.

Theories on residential mobility among the elderly revealed that the elder showed lower level of residential mobility than the younger. The elder who owned the house, family and relatives nearby, and strong social cohesion showed lower level of residential mobility than others (Nelson \& Winter, 1975; Findlay \& Morris, 1976). Residential mobility of the elder, therefore, reflected stronger needs than the younger. Generally, it was reported that the elder undergo stress more by residential mobility than the younger, because they were strained when they had to leave the house, which they have bought with their own income in their youth, and to leave the community where they have been belonged to for long period. The facts that they lost memories connected with old neighbours and the house, and had to leave the things they have cherished gave emotional stress to the elder. Learning how to operate unfamiliar equipments in the new house, and getting to know new neighbours were also strained more for the elder than for the younger (Meeks, 1980). Dissatisfaction at the current house and neighbors, one's retirement, accident, spouse's or intimate friends' death increased intention of residential mobility (Nelson \& Winter, 1975). Particularly, spouse's or intimate friends death was the most affecting factor to residential mobility followed by dependency after growing old. Physical defects increased housing deficit, accordingly decreased housing satisfaction, and eventually increased housing mobility (Morris \& Winter, 1978).

Meanwhile, Seo \& Yoon (2011) remarked decision factors on housing mobility in the US. They insisted that residents much considered the physical condition of the house than service proximity and cost. Property value impacted on the residential mobility indicating that higher satisfaction for property values decreased the housing mobility intention. The mobility intention was more associated with the physical environment than social environment. Kim et al. (2010) found that Korean baby boomers were favored an active post-retirement life where they could enjoy proper leisure without considerable change in daily-routines.
Their housing size showed a downward tendency in response to changes in economic conditions and family members. Im \& Baek (2011) revealed that more than a half of the Korean baby boomers considered moving to smaller house located in near environment after retirement, and they assumed it would influence to Korean housing market.

The residents residing in senior cohousing community thought of mutual support and social interaction among neighbors more important than the younger (Glass, 2009). Glass (2009) found that sense of community was ranked the highest with mutual support motivation to move to senior cohousing in the US. A simplified lifestyle and the spiritual component also highly valued. Several case studies on Scandinavian senior cohousing communities identified residents' motivation to move to cohousing were to seek for smaller house to get rid of burden and worries about housing management after growing old (SBI, 1993; Ambrose, 1993), also to seek for the secure living environment where neighbors can exchange social contacts through shared activity (Jensen,1994). Especially, by a massive social survey targeting more than 500 respondents in Swedish and Danish senior cohousing, main motivation was found as ideological reason followed by housing management reason and environmental reason (Choi \& Cho, 2006). Personal reason, however, revealed as the least affecting reason to move to senior cohousing, opposed to Meeks theory (1980). In other word, spouse's death or devoice did not affect much to move to senior cohousing. These results indicated motivation of move to cohousing might be different from the conventional residential mobility.

\section{METHODS}

\subsection{Research Design}

This research was conducted by mixed methods with studyvisits to cohousing communities in Sweden and quantitative study by questionnaire. Study-visits to cohousing were fulfilled to get knowledge and to understand its' actual condition. In whole, 11 study-visits to cohousing communities were done during the spring of 2010. Study-visits to 5 cohousing communities in Stockholm area were organized by authority of the 1st International Collaborative Housing Conference in May, 2010; Trekanten, Tre Porta, Södra Station Färdknäppen and Sjöfarten. In addition, 6 study-visits in other areas were organized by personal contacts; Russinet and Slottet in Lund, Majbacken, Stacken and Trädet in Göteborg, and Kornet in MöIndal. Of 11 units, 4 belonged to the +40 cohousing and the rests were the mixed-age cohousing. Faceto-face interviews with residents, observation of the communal spaces and individual dwelling units were performed, and common meals for lunch or dinner, coffee and snacks were served during the study-visits. It offered opportunities to comprehend resident's life in Swedish cohousing communities.

The questionnaire was designed from the references of previous researches fulfilled in Danish senior cohousing projects (Ambrose, 1993; Jensen, 1994; Pedersen, 1999, Choi, 2004). To design contents, main reasons to move revealed in the previous studies were collected and divided into 5 categories including 19 reasons. 5 categories were "Personal reason (2 contents)", "Housing management reason (4 contents)", "Security reason (6 contents)", "Environmental reason (6 contents) "and "Ideological reason (1 content)". 


\subsection{Data Collection and Analysis}

Questionnaire survey was fulfilled during the autumn of 2010 in Göteborg, Sweden. Prior to sending questionnaire, the author contacted all chairpersons of 44 cohousing communities contained in the homepage of www.kollektivhus.nu by e-mails explaining purpose of the research and inquired if they would like to join the research. 12 of 44 cohousing communities sent back positive responses. Distributed numbers of questionnaire were intentionally controlled, considering numbers of flats in order to get similar amount of data so that comparison between the 2 cohousing types could be made.

353 questionnaires were sent to representative of each cohousing community by ordinary mail and asked to distribute to the voluntary participants. For privacy reason, completed questionnaires were sent back by ordinary mail individually. Of 353,165 were distributed to the +40 cohousing and 188 to the mixed-age cohousing. Eventually similar amount of data were collected from the 2 groups as 127 ( +40 cohousing) and 115 (mixed-age cohousing), in total 242(68.6\%). Collected data were analyzed by SPSS statistical program.

\subsection{Research Objects}

Research objects are 12 cohousing communities all over Sweden including 4 of the +40 cohousing and 8 of the mixed-age cohousing (Table 1). In Sweden, there are only 6 of the +40 cohousing nationwide, and the rests (38) are the mixed-age cohousing.

Concerning establishment year, the +40 cohousing units were established rather recently after 1994, compared to the mixedage cohousing units that were established mostly in 1980's except Hässelby familijehotel (1959) and Kornet (2006).

Table 1. Object cohousing communities (f(\%))

\begin{tabular}{|c|c|c|c|c|c|}
\hline $\begin{array}{l}\text { Cohous- } \\
\text { ing types }\end{array}$ & $\begin{array}{c}\text { Name } \\
\text { (Established } \\
\text { year) }\end{array}$ & Location & $\begin{array}{l}\text { Total } \\
\text { flats }\end{array}$ & $\begin{array}{l}\text { Distri- } \\
\text { buted } \\
\text { questio- } \\
\text { nnaires }\end{array}$ & $\begin{array}{l}\text { Collected } \\
\text { questio- } \\
\text { nnaires }\end{array}$ \\
\hline \multirow{4}{*}{$\begin{array}{l}+40 \\
\text { cohous- } \\
\text { ing }\end{array}$} & $\begin{array}{l}\text { Fä rdkn- } \\
\text { äppen(1994) }\end{array}$ & Stockholm & 50 & 40 & 26 \\
\hline & $\begin{array}{l}\text { Majbacken } \\
(2003)\end{array}$ & Göteborg & 31 & 31 & 29 \\
\hline & $\begin{array}{l}\text { Sockens- } \\
\text { tugan }(1994)\end{array}$ & Stockholm & 50 & 50 & 34 \\
\hline & Tersen(2004) & Falun & 44 & 44 & 38 \\
\hline \multicolumn{3}{|l|}{ Sub total } & 175 & $\begin{array}{c}165 \\
(100.0)\end{array}$ & $\begin{array}{c}127 \\
(77.0) \\
\end{array}$ \\
\hline \multirow{8}{*}{$\begin{array}{l}\text { Mixed- } \\
\text { age } \\
\text { ohous- } \\
\text { ing }\end{array}$} & $\begin{array}{l}\text { Hässelby } \\
\text { familje } \\
\text { hotel(1959) }\end{array}$ & Stockholm & 40 & 20 & 20 \\
\hline & $\begin{array}{l}\text { Kornet } \\
(2006)\end{array}$ & Möndal & 44 & 44 & 31 \\
\hline & $\begin{array}{l}\text { Prästgår- } \\
\text { dshage(1987) }\end{array}$ & Stockholm & 32 & 15 & 9 \\
\hline & $\begin{array}{l}\text { Stacken } \\
(1980)\end{array}$ & Göteborg & 35 & 20 & 9 \\
\hline & $\begin{array}{l}\text { Stolply- } \\
\text { ckans(1987) }\end{array}$ & Linköping & 49 & 20 & 8 \\
\hline & $\begin{array}{l}\text { Trekanten } \\
(1986)\end{array}$ & Stockholm & 78 & 20 & 12 \\
\hline & Trädet(1985) & Göteborg & 39 & 15 & 11 \\
\hline & Tunnan(1987) & Borås & 34 & 34 & 15 \\
\hline \multicolumn{3}{|l|}{ Sub total } & 351 & $\begin{array}{c}188 \\
(100.0)\end{array}$ & $115(61.2)$ \\
\hline \multicolumn{3}{|l|}{ Total } & 526 & $\begin{array}{c}353 \\
(100.0) \\
\end{array}$ & $242(68.6)$ \\
\hline
\end{tabular}

\section{FINDINGS AND DISCUSSIONS}

\subsection{Difference of Demographic Characteristics and Dwelling Size by Cohousing types}

In whole, demographic characteristics of respondents are summarized as that there are more females (69.4\%) and singles $(59.9 \%)$, mostly healthy $(87.2 \%)$, evenly aged from under 50 s to 70 s and older in their age, highly educated in high school and university (97.5\%), and notable proportions of academics $(38.0 \%)$ and civil workers with long professional education(28.1\%) in occupation. It is coincident with the typical cohousing residents characteristics which were identified in the previous researches (Ambrose, 1993; Choi, 2004; FIC, 2007; Cho \& Choi, 2011).

Table 2. Difference in demographic variables by cohousing types

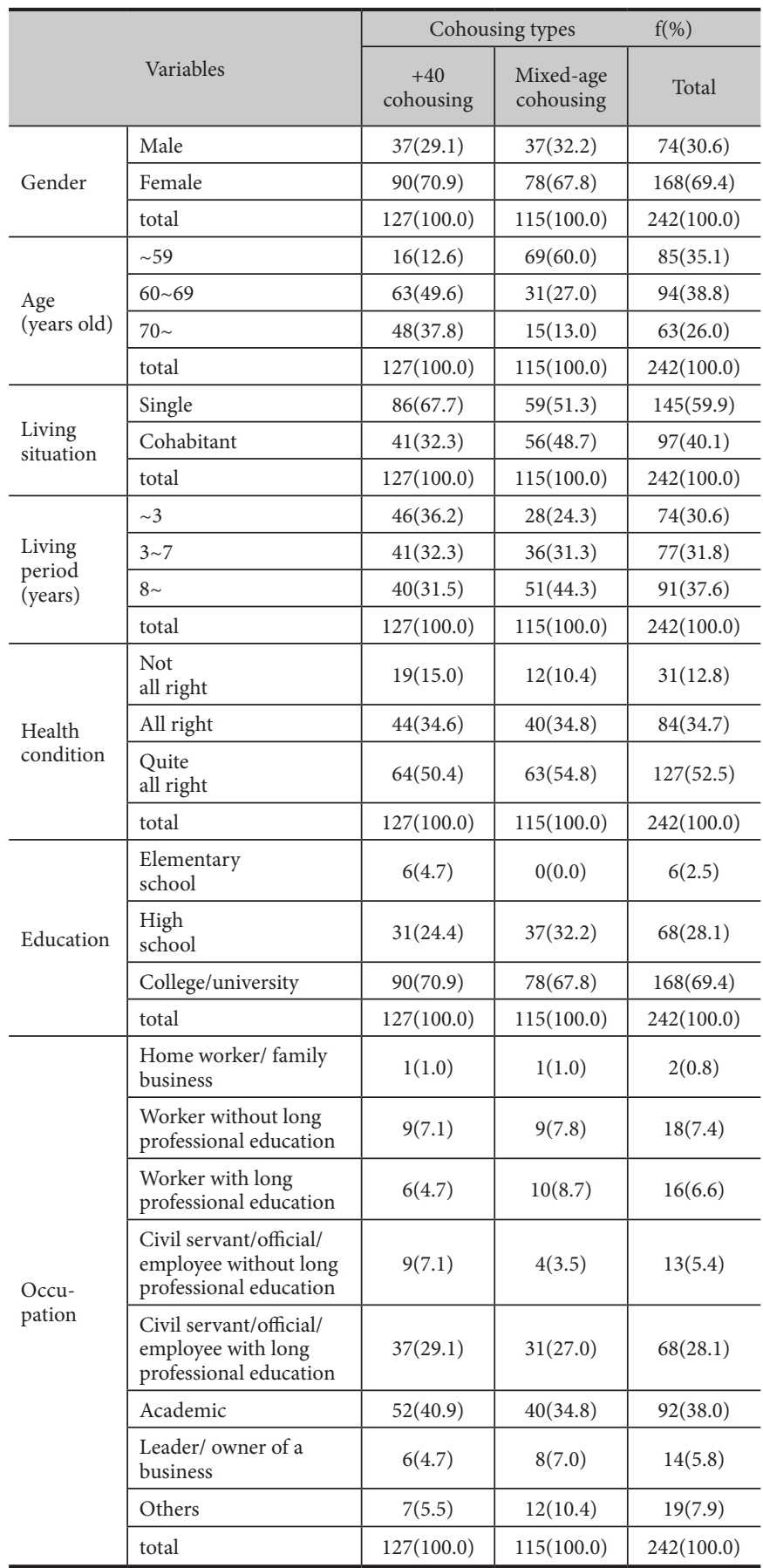


Table 2 shows difference in demographic characteristics between the 2 groups. Notable difference in demographic characteristics by cohousing type is as follows. There are more female $(70.9 \% / 67.8 \%)$ and single $(67.7 \% / 51.3 \%)$ in the +40 cohousing than in the mixedage cohousing. And also there are more college/university graduates $(70.9 \% / 67.8 \%)$ and academics $(40.9 \% / 34.8 \%)$ in the +40 cohousing than in the mixed-age cohousing.

In reference to dwelling size (Table 3), $47.5 \%$ of respondents are living in the $2 R+K$ dwelling (aver. $63 \mathrm{~m}^{2}$ ). Dwelling size is definitely different between the 2 groups because of different family size. Though the most common size is the $2 \mathrm{R}+\mathrm{K}$, its proportion is much higher in the +40 cohousing $(58.7 \%)$ than in the mixedage cohousing (35.7\%). There are even much larger dwellings like the $4 \mathrm{R}+\mathrm{K} \sim$ in the mixed-age cohousing $(34.0 \%)$ than in the +40 cohousing $(3.1 \%)$, reversely 3 times more the $1 R+K$ in the +40 cohousing $(17.3 \%)$ than in the mixed-age cohousing $(6.1 \%)$.

Table 3. Difference in dwelling size by cohousing types

\begin{tabular}{|c|c|c|c|c|}
\hline \multirow{2}{*}{\multicolumn{2}{|c|}{$\begin{array}{l}\text { Dwelling size } \\
\text { (Average 63m2) }\end{array}$}} & \multicolumn{2}{|c|}{ Cohousing types } & $f(\%)$ \\
\hline & & \multirow{2}{*}{$\begin{array}{c}+40 \\
\text { cohousing } \\
22(17.3)\end{array}$} & \multirow{2}{*}{$\begin{array}{c}\begin{array}{c}\text { Mixed- age } \\
\text { cohousing }\end{array} \\
7(6.1)\end{array}$} & \multirow{2}{*}{$\begin{array}{c}\text { total } \\
29(12.0)\end{array}$} \\
\hline \multirow{5}{*}{$\begin{array}{l}\text { Dwelling } \\
\text { size }\end{array}$} & $1 \mathrm{R}+\mathrm{K}$ & & & \\
\hline & $2 \mathrm{R}+\mathrm{K}$ & $74(58.7)$ & $41(35.7)$ & $115(47.5)$ \\
\hline & $3 R+K$ & $27(21.3)$ & $29(25.2)$ & $56(23.1)$ \\
\hline & $4 \mathrm{R}+\mathrm{K} \sim$ & $4(3.1)$ & $32(34.0)$ & $36(17.4)$ \\
\hline & total & $127(100.0)$ & $115(100.0)$ & $242(100.0)$ \\
\hline
\end{tabular}

\subsection{Motivation of Move to Cohousing}

Motivation to move to cohousing was composed of 5 categories including 19 reasons (Table 4). It was measured by 4 scores Likertscale (1:yes to a high extent $\sim 4$ :no, not at all), which means 76 scores maximum. Of 5 categories, security reasons $(\mathrm{m}=16.72 / 24.00)$ and ideological reason $(\mathrm{m}=3.29 / 4.00)$ are revealed as more important than others, while personal reasons $(\mathrm{m}=3.76 / 12.00)$ and housing management reasons $(\mathrm{m}=7.70 / 20.00)$ are regarded as less important than others. This result is quite different from the previous researches, which showed housing management reasons as the most important reason to move to cohousing. It might cause from the different research subject from the previous researches dealt with only seniors.

Of 19 reasons, 3 reasons as "good contact with other inhabitants" $(\mathrm{m}=3.37 / 4.00)$, "sharing common activity" $(\mathrm{m}=3.28 / 4.00)$ and "idea of cohousing" ( $\mathrm{m}=3.29 / 4.00)$ are noticed as the main reasons why people move to cohousing community in Sweden.

Table 4. Moving motivation to cohousing in total, $\mathrm{f}(\%), \mathrm{n}=242$

\begin{tabular}{l|l|c|c|c|c|c}
\hline \multirow{2}{*}{ Category } & Reason & $\begin{array}{c}\text { Yes, to } \\
\text { a high } \\
\text { extent }\end{array}$ & $\begin{array}{c}\text { Yes, to } \\
\text { some } \\
\text { extent }\end{array}$ & $\begin{array}{c}\text { No, } \\
\text { hardly }\end{array}$ & $\begin{array}{c}\text { No, } \\
\text { not at } \\
\text { all }\end{array}$ & Mean \\
\hline \multirow{2}{*}{$\begin{array}{l}\text { Personal } \\
\text { reasons } \\
\text { mean= } \\
3.76 / 12.00\end{array}$} & $\begin{array}{l}\text { Because I } \\
\text { became a } \\
\text { pensioner }\end{array}$ & $\begin{array}{l}7 \\
(2.9)\end{array}$ & $\begin{array}{c}23 \\
(9.5)\end{array}$ & $\begin{array}{c}18 \\
(7.4)\end{array}$ & $\begin{array}{c}194 \\
(80.2)\end{array}$ & 1.35 \\
\cline { 2 - 7 } & Because I & 8 & $\begin{array}{c}21 \\
(8.7)\end{array}$ & $\begin{array}{c}6 \\
(2.5)\end{array}$ & $\begin{array}{c}207 \\
(85.5)\end{array}$ & 1.30 \\
\cline { 2 - 7 } & $\begin{array}{l}\text { Because my } \\
\text { husband/ } \\
\text { wife died }\end{array}$ & $\begin{array}{c}5 \\
(2.1)\end{array}$ & $\begin{array}{c}6 \\
(2.5)\end{array}$ & $\begin{array}{c}1 \\
(0.4)\end{array}$ & $\begin{array}{c}230 \\
(95.0)\end{array}$ & 1.12 \\
\hline
\end{tabular}

\begin{tabular}{|c|c|c|c|c|c|c|}
\hline \multirow{5}{*}{$\begin{array}{l}\text { Housing } \\
\text { manage- } \\
\text { ment } \\
\text { reasons } \\
\text { mean= } \\
7.70 / 20.00\end{array}$} & $\begin{array}{l}\text { To live in } \\
\text { a building } \\
\text { which is } \\
\text { adapted } \\
\text { to elderly/ } \\
\text { children }\end{array}$ & $\begin{array}{c}33 \\
(13.6)\end{array}$ & $\begin{array}{c}39 \\
(16.1)\end{array}$ & $\begin{array}{c}18 \\
(7.4)\end{array}$ & $\begin{array}{c}152 \\
(62.8)\end{array}$ & 1.80 \\
\hline & $\begin{array}{l}\text { To get a } \\
\text { smaller } \\
\text { dwelling }\end{array}$ & $\begin{array}{l}17 \\
(7.0)\end{array}$ & $\begin{array}{c}51 \\
(21.1)\end{array}$ & $\begin{array}{c}13 \\
(5.4)\end{array}$ & $\begin{array}{c}161 \\
(66.5)\end{array}$ & 1.69 \\
\hline & $\begin{array}{l}\text { To escape } \\
\text { from worries } \\
\text { about house } \\
\text { and garden }\end{array}$ & $\begin{array}{c}11 \\
(4.6)\end{array}$ & $\begin{array}{c}37 \\
(15.4)\end{array}$ & $\begin{array}{c}20 \\
(8.3)\end{array}$ & $\begin{array}{c}173 \\
(71.8)\end{array}$ & 1.53 \\
\hline & $\begin{array}{l}\text { To live in a } \\
\text { house which } \\
\text { is adapted } \\
\text { to elderly/ } \\
\text { disabled } \\
\text { person }\end{array}$ & $\begin{array}{c}5 \\
(2.1)\end{array}$ & $\begin{array}{c}27 \\
(11.2)\end{array}$ & $\begin{array}{c}16 \\
(6.6)\end{array}$ & $\begin{array}{c}194 \\
(80.2)\end{array}$ & 1.35 \\
\hline & $\begin{array}{l}\text { To get } \\
\text { a larger } \\
\text { dwelling }\end{array}$ & $\begin{array}{c}14 \\
(5.8)\end{array}$ & $\begin{array}{c}15 \\
(6.2)\end{array}$ & $\begin{array}{c}8 \\
(3.3)\end{array}$ & $\begin{array}{c}205 \\
(84.7)\end{array}$ & 1.33 \\
\hline \multirow{4}{*}{$\begin{array}{l}\text { Environ- } \\
\text { mental } \\
\text { reasons } \\
\text { mean= } \\
8.82 / 16.00\end{array}$} & $\begin{array}{l}\text { Because the } \\
\text { building is } \\
\text { very well } \\
\text { situated in } \\
\text { town }\end{array}$ & $\begin{array}{c}36 \\
(14.9)\end{array}$ & $\begin{array}{c}95 \\
(39.3)\end{array}$ & $\begin{array}{c}49 \\
(20.2)\end{array}$ & $\begin{array}{c}62 \\
(25.6)\end{array}$ & 2.44 \\
\hline & $\begin{array}{l}\text { Because the } \\
\text { building is } \\
\text { well planned } \\
\text { and beautiful }\end{array}$ & $\begin{array}{c}32 \\
(13.2)\end{array}$ & $\begin{array}{c}85 \\
(34.8)\end{array}$ & $\begin{array}{c}51 \\
(21.1)\end{array}$ & $\begin{array}{c}74 \\
(30.6)\end{array}$ & 2.31 \\
\hline & $\begin{array}{l}\text { To come } \\
\text { closer to } \\
\text { cultural } \\
\text { events/ } \\
\text { activities }\end{array}$ & $\begin{array}{c}27 \\
(11.2)\end{array}$ & $\begin{array}{c}53 \\
(21.9)\end{array}$ & $\begin{array}{c}65 \\
(26.9)\end{array}$ & $\begin{array}{c}97 \\
(40.1)\end{array}$ & 2.03 \\
\hline & $\begin{array}{l}\text { To come } \\
\text { closer to the } \\
\text { nature }\end{array}$ & $\begin{array}{c}25 \\
(10.3)\end{array}$ & $\begin{array}{c}58 \\
(24.0)\end{array}$ & $\begin{array}{c}59 \\
(24.4)\end{array}$ & $\begin{array}{c}100 \\
(41.3)\end{array}$ & 2.03 \\
\hline \multirow{6}{*}{ 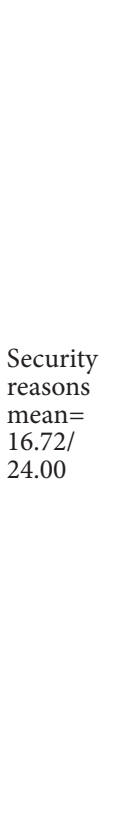 } & $\begin{array}{l}\text { To live } \\
\text { in good } \\
\text { contacts } \\
\text { with other } \\
\text { inhabitants }\end{array}$ & $\begin{array}{c}133 \\
(55.0)\end{array}$ & $\begin{array}{c}85 \\
(35.1)\end{array}$ & $\begin{array}{c}6 \\
(2.5)\end{array}$ & $\begin{array}{c}18 \\
(7.4)\end{array}$ & 3.37 \\
\hline & $\begin{array}{l}\text { To be } \\
\text { together } \\
\text { with } \\
\text { neighbors } \\
\text { in common } \\
\text { activities }\end{array}$ & $\begin{array}{c}117 \\
(48.5)\end{array}$ & $\begin{array}{c}94 \\
(39.0)\end{array}$ & $\begin{array}{c}10 \\
(4.1)\end{array}$ & $\begin{array}{c}20 \\
(8.3)\end{array}$ & 3.28 \\
\hline & $\begin{array}{l}\text { To have } \\
\text { mutual } \\
\text { support with } \\
\text { neighbors }\end{array}$ & $\begin{array}{c}81 \\
(33.5)\end{array}$ & $\begin{array}{c}91 \\
(37.6)\end{array}$ & $\begin{array}{c}31 \\
(12.8)\end{array}$ & $\begin{array}{c}39 \\
(16.1)\end{array}$ & 2.88 \\
\hline & $\begin{array}{l}\text { Not to be } \\
\text { alone }\end{array}$ & $\begin{array}{c}70 \\
(28.9)\end{array}$ & $\begin{array}{c}97 \\
(40.1)\end{array}$ & $\begin{array}{c}24 \\
(9.9)\end{array}$ & $\begin{array}{c}51 \\
(21.4)\end{array}$ & 2.78 \\
\hline & $\begin{array}{l}\text { To feel } \\
\text { security }\end{array}$ & $\begin{array}{c}47 \\
(19.4)\end{array}$ & $\begin{array}{c}87 \\
(36.0)\end{array}$ & $\begin{array}{c}31 \\
(12.8)\end{array}$ & $\begin{array}{c}77 \\
(31.8)\end{array}$ & 2.42 \\
\hline & $\begin{array}{l}\text { Because I } \\
\text { knew other } \\
\text { inhabitants } \\
\text { in the unit }\end{array}$ & $\begin{array}{c}32 \\
(13.2)\end{array}$ & $\begin{array}{c}57 \\
(23.6)\end{array}$ & $\begin{array}{c}32 \\
(13.2)\end{array}$ & $\begin{array}{c}121 \\
(50.0)\end{array}$ & 2.00 \\
\hline $\begin{array}{l}\text { Ideo- } \\
\text { logical } \\
\text { reason } \\
\text { mean= } \\
3.29 / 4.00\end{array}$ & $\begin{array}{l}\text { Because I } \\
\text { like the idea } \\
\text { of cohousing }\end{array}$ & $\begin{array}{c}149 \\
(61.6)\end{array}$ & $\begin{array}{c}44 \\
(18.2)\end{array}$ & $\begin{array}{c}18 \\
(7.4)\end{array}$ & $\begin{array}{c}31 \\
(12.8)\end{array}$ & 3.29 \\
\hline
\end{tabular}


Table 5. Personal reasons by cohousing types

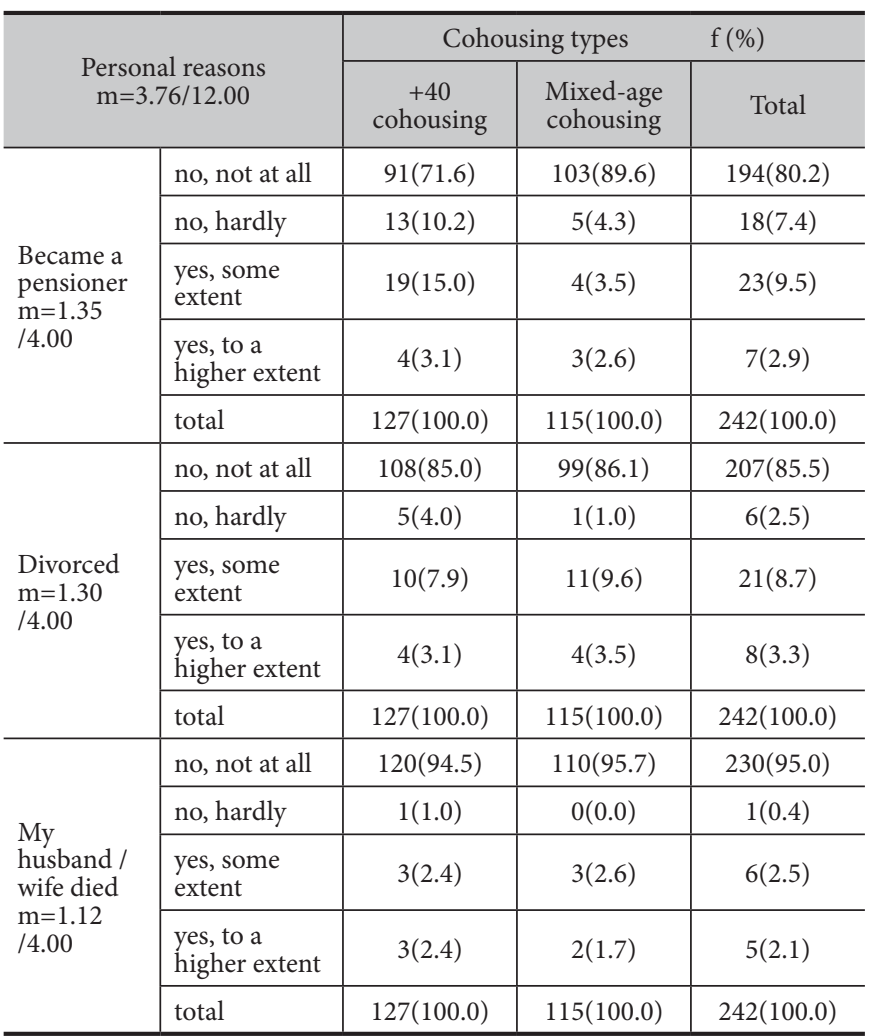

Table 5 indicates personal reasons. Though personal reasons reveal as less important motivation to move to cohousing, minor difference between the 2 groups are found. Divorce or spouse's death is not regarded as important reasons to move to cohousing without any significant difference between the 2 groups. However, being a pensioner, naturally, influence residents to move to cohousing community more in the +40 cohousing $(18.1 \%)$ than in the mixed-age cohousing $(6.1 \%)$. The theories by Nelson \& Winter(1975) and Morris \& Winter(1978) that spouse's or intimate friends' death increase intention of residential mobility are not appropriate to explain this result. This difference might come from the different housing types; ordinary house vs. cohousing.

Table 6. Mean comparison of personal reasons by cohousing types

\begin{tabular}{l|c|c|c}
\hline \multirow{2}{*}{} & \multicolumn{3}{|c}{ Cohousing types } \\
\cline { 2 - 4 } & +40 cohousing & $\begin{array}{c}\text { Mixed-age } \\
\text { cohousing }\end{array}$ & T value \\
\hline $\begin{array}{l}\text { PERSONAL } \\
\text { REASONS }\end{array}$ & 3.91 & 3.60 & $2.011^{* *}$ \\
\hline $\begin{array}{l}\text { Became a } \\
\text { pensioner }\end{array}$ & 1.50 & 1.30 & 0.132 \\
\hline $\begin{array}{l}\text { Divorced } \\
\begin{array}{l}\text { Husband and wife } \\
\text { died }\end{array}\end{array}$ & 1.29 & 1.10 & 0.319 \\
\hline
\end{tabular}

${ }^{* * *} \mathrm{p}<.001 ;{ }^{* *} \mathrm{p}<.01 ;{ }^{*} \mathrm{p}<.05$

Mean comparison of total personal reasons are different between the 2 groups with statistical significance (Table 6). It means residents of the +40 cohousing are more affected $(\mathrm{m}=3.91)$ by personal reasons to move to cohousing than of the mixed-age cohousing $(\mathrm{m}=3.60)(\mathrm{p}<.01)$. But, in detail, spouse's death affects slightly more to residents of the mixed-age cohousing (1.19) than of the +40 cohousing (1.13) as a reason to move to cohousing $(\mathrm{p}<.001)$.

Housing management reasons, as same as personal reasons, are not considered as important motivation to move, indicating total mean score 7.70 of 20.00 (Table 7). But if you look at the result carefully, notable and interesting differences between the 2 groups are found. All the reasons except "to escape from worries about the house and garden" are definitely different between the 2 groups. In the mixed-age cohousing, for instance, residents think of larger house and the house adapted to elderly/children more important, but smaller house and the house adapted to elderly/disabled are regarded more important in the +40 cohousing.

Table 7. Housing management reasons by cohousing types

\begin{tabular}{|c|c|c|c|c|}
\hline \multirow{2}{*}{\multicolumn{2}{|c|}{$\begin{array}{c}\text { Housing management } \\
\text { reasons } \\
\mathrm{m}=7.70 / 20.00\end{array}$}} & \multicolumn{2}{|c|}{ Cohousing types } & \multirow{3}{*}{$\begin{array}{c}\mathrm{f}(\%) \\
\text { Total } \\
174(71.9)\end{array}$} \\
\hline & & $\begin{array}{l}+40 \\
\text { cohousing }\end{array}$ & $\begin{array}{l}\text { Mixed-age } \\
\text { cohousing }\end{array}$ & \\
\hline \multirow{5}{*}{$\begin{array}{l}\text { To escape } \\
\text { from } \\
\text { worries } \\
\text { about the } \\
\text { house and } \\
\text { garden } \\
\mathrm{m}=1.52 \\
/ 4.00\end{array}$} & no, not at all & $89(70.1)$ & $85(74.9)$ & \\
\hline & no, hardly & $10(7.9)$ & $10(8.7)$ & $20(8.3)$ \\
\hline & $\begin{array}{l}\text { yes, some } \\
\text { extent }\end{array}$ & $20(15.7)$ & $17(14.8)$ & $37(15.3)$ \\
\hline & $\begin{array}{l}\text { yes, to a } \\
\text { higher extent }\end{array}$ & $8(6.3)$ & $3(2.6)$ & $11(4.5)$ \\
\hline & total & $127(100.0)$ & $115(100.0)$ & $242(100.0)$ \\
\hline \multirow{5}{*}{$\begin{array}{l}\text { To get a } \\
\text { smaller } \\
\text { house } \\
\mathrm{m}=1.69 \\
/ 4.00\end{array}$} & no, not at all & $72(56.7)$ & $89(77.4)$ & $161(66.5)$ \\
\hline & no, hardly & $11(8.7)$ & $2(1.7)$ & $13(5.4)$ \\
\hline & $\begin{array}{l}\text { yes, some } \\
\text { extent }\end{array}$ & $33(26.0)$ & $18(15.7)$ & $51(21.1)$ \\
\hline & $\begin{array}{l}\text { yes, to a } \\
\text { higher extent }\end{array}$ & $11(8.7)$ & $6(5.2)$ & $17(7.0)$ \\
\hline & total & $127(100.0)$ & $115(100.0)$ & $242(100.0)$ \\
\hline \multirow{5}{*}{$\begin{array}{l}\text { To get } \\
\text { a larger } \\
\text { house } \\
\mathrm{m}=1.33 \\
/ 4.00\end{array}$} & no, not at all & $120(94.5)$ & $85(73.9)$ & $205(84.7)$ \\
\hline & no, hardly & $5(3.9)$ & $3(2.6)$ & $8(3.3)$ \\
\hline & $\begin{array}{l}\text { yes, some } \\
\text { extent }\end{array}$ & $2(1.6)$ & $13(11.3)$ & $15(6.2)$ \\
\hline & $\begin{array}{l}\text { yes, to a } \\
\text { higher extent }\end{array}$ & $0(0.0)$ & $14(12.28)$ & $14(5.8)$ \\
\hline & total & $127(100.0)$ & $115(100.0)$ & $242(100.0)$ \\
\hline \multirow{5}{*}{$\begin{array}{l}\text { To live in } \\
\text { a house } \\
\text { which is } \\
\text { adapted to } \\
\text { elderly / } \\
\text { disabled } \\
\text { persons } \\
\mathrm{m}=1.35 \\
/ 4.00\end{array}$} & no, not at all & $89(70.1)$ & 105(91.3) & $194(80.2)$ \\
\hline & no, hardly & $12(9.4)$ & $4(3.5)$ & $16(6.6)$ \\
\hline & $\begin{array}{l}\text { yes, some } \\
\text { extent }\end{array}$ & $22(17.3)$ & $5(4.3)$ & $27(11.2)$ \\
\hline & $\begin{array}{l}\text { yes, to a } \\
\text { higher extent }\end{array}$ & $4(3.1)$ & $1(1.0)$ & $5(2.1)$ \\
\hline & total & $127(100.0)$ & $115(100.0)$ & $242(100.0)$ \\
\hline \multirow{5}{*}{$\begin{array}{l}\text { To live in } \\
\text { a building } \\
\text { which is } \\
\text { adapted to } \\
\text { elderly / } \\
\text { children } \\
\mathrm{m}=1.81 \\
/ 4.00\end{array}$} & no, not at all & $89(70.1)$ & $63(54.8)$ & $152(62.8)$ \\
\hline & no, hardly & $11(8.7)$ & $7(6.1)$ & $18(7.4)$ \\
\hline & $\begin{array}{l}\text { yes, some } \\
\text { extent }\end{array}$ & $24(18.9)$ & $15(13.4)$ & $39(16.1)$ \\
\hline & $\begin{array}{l}\text { yes, to a } \\
\text { higher extent }\end{array}$ & $3(2.4)$ & $30(26.1)$ & $33(13.6)$ \\
\hline & total & $127(100.0)$ & $115(100.0)$ & $242(100.0)$ \\
\hline
\end{tabular}


This result reflects different needs of each cohousing types in context of age groups/life-stage.

Though differences of total means between the 2 groups are not statistically significant, means of 4 reasons except "to escape from worries about the house and garden" indicate considerable differences between the 2 groups with statistical significance (Table 8). In detail, more residents of the +40 cohousing move to cohousing "to get a smaller house" $(\mathrm{m}=1.87)$ and "to live in a house adapted to the elderly/ disabled $(\mathrm{m}=1.54)$ than of the mixed aged cohousing" $(\mathrm{m}=1.49)(\mathrm{m}=1.15)(\mathrm{p} .<001)$. Reversely, more residents of the mixed-aged cohousing move to cohousing "to get a larger house" ( $\mathrm{m}=1.62)$ and "to live in a house adapted to the elderly/ children" ( $\mathrm{m}=2.10)$ than of the +40 cohousing $(\mathrm{m}=1.07)(\mathrm{m}=1.54)$ (p. <001). It evidently matters with family size and life-stagey.

It is interesting to find quite different result from the previous researches that main motivation to move to senior cohousing was revealed as housing management reasons, especially "to escape from worries about the house and garden" (Ambrose, 1993; Pedersen,1999; Choi, 2004; Choi \& Paulsson, 2006). This different result might be related to the previous researches' subjects concerned with only seniors aged 55 or elder. It must be difficult for older people to manage the house and garden on their own so, they would like to escape worries about the house and garden by moving into cohousing community.

Table 8. Mean comparison of housing management reasons by cohousing types

\begin{tabular}{l|c|c|c}
\hline \multirow{2}{*}{} & \multicolumn{3}{|c}{ Cohousing types } \\
\cline { 2 - 4 } & $\begin{array}{c}+40 \\
\text { cohousing }\end{array}$ & $\begin{array}{c}\text { Mixed- age } \\
\text { cohousing }\end{array}$ & T value \\
\hline $\begin{array}{l}\text { HOUSING } \\
\text { MANAGEMENT } \\
\text { REASONS }\end{array}$ & 7.59 & 7.82 & -0.663 \\
\hline $\begin{array}{l}\text { To escape from } \\
\text { worries about } \\
\text { house and garden }\end{array}$ & 1.58 & 1.46 & 1.038 \\
\hline $\begin{array}{l}\text { To get a smaller } \\
\text { house }\end{array}$ & 1.87 & 1.49 & $2.901^{* * *}$ \\
\hline $\begin{array}{l}\text { To get a larger } \\
\text { house }\end{array}$ & 1.07 & 1.62 & $-5.379^{* * *}$ \\
\hline $\begin{array}{l}\text { To live in a house } \\
\text { which is adapted } \\
\text { to elderly/disabled } \\
\text { persons }\end{array}$ & 1.54 & 1.15 & $4.090^{* * *}$ \\
\hline $\begin{array}{l}\text { To live in a house } \\
\text { which is adapted to } \\
\text { elderly/children }\end{array}$ & 1.54 & 2.10 & $-3.991^{* * *}$ \\
\hline
\end{tabular}

${ }^{* * *} \mathrm{p}<.001 ;{ }^{* *} \mathrm{p}<.01 ;{ }^{*} \mathrm{p}<.05$

Security reasons are identified as one of the major reasons for residents to move to cohousing, showing total mean score 16.72 of 24.00 (Table 9). Remarkably, 2 reasons of "to live in good contacts with other inhabitants" $(\mathrm{m}=3.38 / 4.00)$ and "to be together with neighbors in common activities" $(\mathrm{m}=3.27 / 4.00)$ turn up as significant motivations, followed by "mutual supports with neighbors" ( $\mathrm{m}=2.88 / 4.00)$. It is coincident with the result of the previous researches (Ambrose, 1993; Pedersen, 1999; Choi, 2004; Choi \& Paulsson, 2006) and is natural for cohousers who seek for social interaction in the community.
Table 9. Security reasons by cohousing types

\begin{tabular}{|c|c|c|c|c|}
\hline \multirow{2}{*}{\multicolumn{2}{|c|}{$\begin{array}{l}\text { Security reasons } \\
\mathrm{m}=16.72 / 24.00\end{array}$}} & \multicolumn{2}{|c|}{ Cohousing types } & \multirow{3}{*}{$\begin{array}{c}\mathrm{f}(\%) \\
\text { Total } \\
77(31.8)\end{array}$} \\
\hline & & \multirow{2}{*}{$\begin{array}{c}\begin{array}{c}+40 \\
\text { cohousing }\end{array} \\
39(30.7)\end{array}$} & \multirow{2}{*}{$\begin{array}{c}\text { Mixed-age } \\
\text { cohousing }\end{array}$} & \\
\hline \multirow{5}{*}{$\begin{array}{l}\text { To feel } \\
\text { security } \\
\mathrm{m}=2.43 / 4.00\end{array}$} & no, not at all & & & \\
\hline & no, hardly & $17(13.4)$ & $14(12.2)$ & $31(12.8)$ \\
\hline & $\begin{array}{l}\text { yes, some } \\
\text { extent }\end{array}$ & $43(33.9)$ & $44(38.3)$ & $87(36.0)$ \\
\hline & $\begin{array}{l}\text { yes, to a } \\
\text { higher } \\
\text { extent }\end{array}$ & $28(22.0)$ & $19(16.5)$ & $47(19.4)$ \\
\hline & total & $127(100.0)$ & $115(100.0)$ & $242(100.0)$ \\
\hline \multirow{5}{*}{$\begin{array}{l}\text { Not to be } \\
\text { alone } \\
\mathrm{m}=2.77 / 4.00\end{array}$} & no, not at all & $24(18.9)$ & $27(23.5)$ & $51(21.1)$ \\
\hline & no, hardly & $7(5.5)$ & $17(14.8)$ & $24(9.9)$ \\
\hline & $\begin{array}{l}\text { yes, some } \\
\text { extent }\end{array}$ & $58(45.7)$ & $39(33.9)$ & $97(40.1)$ \\
\hline & $\begin{array}{l}\text { yes, to a } \\
\text { higher } \\
\text { extent }\end{array}$ & $38(29.2)$ & $32(27.8)$ & $70(28.9)$ \\
\hline & total & $127(100.0)$ & $115(100.0)$ & $242(100.0)$ \\
\hline \multirow{5}{*}{$\begin{array}{l}\text { To live } \\
\text { in good } \\
\text { contacts } \\
\text { with other } \\
\text { inhabitants } \\
\mathrm{m}=3.38 / 4.00\end{array}$} & no, not at all & $5(3.9)$ & $13(11.3)$ & $18(7.4)$ \\
\hline & no, hardly & $1(1.0)$ & $5(4.3)$ & $6(2.5)$ \\
\hline & $\begin{array}{l}\text { yes, some } \\
\text { extent }\end{array}$ & $49(38.6)$ & $36(31.3)$ & $85(35.1)$ \\
\hline & $\begin{array}{l}\text { yes, to a } \\
\text { higher } \\
\text { extent }\end{array}$ & $72(56.7)$ & $61(53.0)$ & $133(55.0)$ \\
\hline & total & $127(100.0)$ & $115(100.0)$ & $242(100.0)$ \\
\hline \multirow{5}{*}{$\begin{array}{l}\text { To give / } \\
\text { have mutual } \\
\text { support / } \\
\text { help to / } \\
\text { from } \\
\text { neighbors } \\
\mathrm{m}=2.8 \text { /4.00 }\end{array}$} & no, not at all & $16(12.6)$ & $23(20.0)$ & $39(16.1)$ \\
\hline & no, hardly & $19(15.0)$ & $12(10.4)$ & $31(12.8)$ \\
\hline & $\begin{array}{l}\text { yes, some } \\
\text { extent }\end{array}$ & $48(37.8)$ & $43(37.4)$ & $91(37.6)$ \\
\hline & $\begin{array}{l}\text { yes, to a } \\
\text { higher } \\
\text { extent }\end{array}$ & $44(34.6)$ & $37(32.2)$ & $81(33.5)$ \\
\hline & total & $127(100.0)$ & $115(100.0)$ & $242(100.0)$ \\
\hline \multirow{5}{*}{$\begin{array}{l}\text { To be } \\
\text { together } \\
\text { with } \\
\text { neighbors } \\
\text { in common } \\
\text { activities } \\
\mathrm{m}=3.27 / 4.00\end{array}$} & no, not at all & $10(7.9)$ & $11(9.6)$ & $21(8.7)$ \\
\hline & no, hardly & $5(3.9)$ & $5(4.3)$ & $10(4.1)$ \\
\hline & $\begin{array}{l}\text { yes, some } \\
\text { extent }\end{array}$ & $49(38.6)$ & $45(39.1)$ & $94(38.8)$ \\
\hline & $\begin{array}{l}\text { yes, to a } \\
\text { higher } \\
\text { extent }\end{array}$ & $63(49.6)$ & $54(47.0)$ & $117(48.3)$ \\
\hline & total & $127(100.0)$ & $115(100.0)$ & $242(100.0)$ \\
\hline \multirow{5}{*}{$\begin{array}{l}\text { Because I } \\
\text { knew other } \\
\text { inhabitants } \\
\text { in the unit } \\
\mathrm{m}=2.00 / 4.00\end{array}$} & no, not at all & $65(51.2)$ & $56(48.7)$ & $121(50.0)$ \\
\hline & no, hardly & $16(12.6)$ & $16(13.9)$ & $32(13.2)$ \\
\hline & $\begin{array}{l}\text { yes, some } \\
\text { extent }\end{array}$ & $32(25.2)$ & $25(21.7)$ & $57(23.6)$ \\
\hline & $\begin{array}{l}\text { yes, to a } \\
\text { higher } \\
\text { extent }\end{array}$ & $14(11.0)$ & $18(15.7)$ & $32(13.2)$ \\
\hline & total & $127(100.0)$ & $115(100.0)$ & $242(100.0)$ \\
\hline
\end{tabular}

Although residents of the +40 cohousing think of security reasons a bit more important $(\mathrm{m}=17.02)$ than ones of the mixedage cohousing $(\mathrm{m}=16.40)$ in total, mean comparison between the 2 groups does not show any statistically significant difference except "to live in a good contact with other inhabitants" ( $\mathrm{p}<.05)$ (Table 10). 
Table 10. Mean comparison of security reasons by cohousing types

\begin{tabular}{l|c|c|c}
\hline \multirow{2}{*}{} & \multicolumn{3}{|c}{ Cohousing types } \\
\cline { 2 - 4 } & $\begin{array}{c}+40 \\
\text { cohousing }\end{array}$ & $\begin{array}{c}\text { Mixed-age } \\
\text { cohousing }\end{array}$ & t value \\
\hline SECURITY REASONS & 17.02 & 16.40 & 1.173 \\
\hline To feel security & 2.47 & 2.38 & 0.617 \\
\hline Not to be alone & 2.87 & 2.66 & 1.470 \\
\hline $\begin{array}{l}\text { To live in good contacts } \\
\text { with other inhabitants }\end{array}$ & 3.48 & 3.26 & $2.003^{*}$ \\
\hline $\begin{array}{l}\text { To give/have mutual } \\
\text { support/help to/from } \\
\text { neighbors }\end{array}$ & 2.94 & 2.82 & 0.945 \\
\hline $\begin{array}{l}\text { To be together with } \\
\text { neighbors in common } \\
\text { activities }\end{array}$ & 3.30 & 3.23 & 0.558 \\
\hline $\begin{array}{l}\text { Because I knew other } \\
\text { inhabitants in the unit }\end{array}$ & 1.96 & 2.04 & -0.570 \\
\hline
\end{tabular}

${ }^{* * *} \mathrm{p}<.001 ;{ }^{* *} \mathrm{p}<.01 ;{ }^{*} \mathrm{p}<.05$

Residents of the +40 cohousing tend to give a bit higher score to "good contact with other inhabitants" $(m=3.48)$ than ones of the mixed-age cohousing $(\mathrm{m}=3.26)$ as a moving motivation. It can be interpreted as that most residents think of security reasons very important motivation to move to cohousing without any difference.

Ideological reason is found as a highly valued motivation to move $(m=3.29 / 4.00)$. More than $62 \%$ of the respondents agree that they moved to cohousing because they like the idea of cohousing to a higher extent (61.6\%), as well as to some extent (18.2\%), all in all it turn up approx. $80 \%$ of positive response (Table 11). Mean scores between the 2 groups are different with statistical significance $(\mathrm{p}<.001)$ (Table 12). It means there are more residents of the +40 cohousing $(\mathrm{m}=3.44)$ than ones of the mixed-age cohousing $(\mathrm{m}=3.11)$ who have moved to cohousing because they like the idea of cohousing. This result shows that the +40 cohousing unit could be considered as one of the advisable housing solutions for the people who want to spend successful second half of life.

Table 11. Ideological reason by cohousing types

\begin{tabular}{|c|c|c|c|c|}
\hline \multirow{2}{*}{\multicolumn{2}{|c|}{$\begin{array}{c}\text { Ideological reason } \\
\mathrm{m}=3.29 / 4.00\end{array}$}} & \multicolumn{2}{|c|}{ Cohousing types } & \multirow{2}{*}{$\frac{f(\%)}{\text { Total }}$} \\
\hline & & +40 & Mixed-age & \\
\hline \multirow{5}{*}{$\begin{array}{l}\text { like the } \\
\text { idea of } \\
\text { cohousing } \\
\mathrm{m}=3.29 \\
/ 4.00\end{array}$} & $\begin{array}{l}\text { no, not } \\
\text { at all }\end{array}$ & $10(7.9)$ & $21(18.3)$ & $31(12.8)$ \\
\hline & no, hardly & $9(7.1)$ & $9(7.8)$ & $18(7.4)$ \\
\hline & $\begin{array}{l}\text { yes, some } \\
\text { extent }\end{array}$ & $23(18.1)$ & $21(18.3)$ & $44(18.2)$ \\
\hline & $\begin{array}{l}\text { to a higher } \\
\text { extent }\end{array}$ & $85(66.9)$ & $64(55.7)$ & $149(61.6)$ \\
\hline & total & $127(100.0)$ & $115(100.0)$ & $242(100.0)$ \\
\hline
\end{tabular}

Table 12. Table 12. Mean comparison of ideological reason by cohousing types

\begin{tabular}{l|c|c|c}
\hline \multirow{2}{*}{} & \multicolumn{3}{|c}{ Cohousing types } \\
\cline { 2 - 4 } & $\begin{array}{c}+40 \\
\text { cohousing }\end{array}$ & $\begin{array}{c}\text { Mixed-age } \\
\text { cohousing }\end{array}$ & T value \\
\hline IDEOLOGICAL REASON & 3.44 & 3.11 & $2.425^{* * *}$ \\
\hline $\begin{array}{l}\text { Because I like the idea of } \\
\text { cohousing }\end{array}$ & 3.44 & 3.11 & $2.425^{* * *}$ \\
\hline
\end{tabular}

${ }^{* * *} \mathrm{p}<.001 ;{ }^{* *} \mathrm{p}<.01 ;{ }^{*} \mathrm{p}<.05$

\section{CONCLUSIONS}

Choice of housing environment is a very important issue for everyone, since housing satisfaction affects one's quality of life. Cohousing is an innovative form of accommodation offering economic, environmental and social advantages over existing forms of housing development.

In this research, motivation of move to cohousing communities in Sweden was investigated to find out the reasons why people choose cohousing for their living. Among the motivation of 5 categories, security reason and ideological reason were revealed as more important than others, on the contrary personal reason and housing management reason were regarded as less important than others. This result was quite different from the previous researches, which showed housing management reason as the most important motivation of move to cohousing. It might cause from the different research object of the previous researches dealt with only seniors aged over 55. In other words, residents move to cohousing wanting to have good contact with other inhabitants through sharing activities according to the idea of cohousing

In addition, motivation of move to cohousing is evidently different influenced by cohousing types which have different residents' characteristics in age, family size and life-stage. Residents of the +40 cohousing tend to stress more on social interaction with neighbours and physical features of the house adapted to the elderly. On the contrary, the mixed-age cohousing residents tend to focus more to practical advantage than social interaction; they prefer physical features of the house adapted to children or to bigger family size. Therefore, cohousing design has to be tailored to adapt residents' specific needs of different life-stages. It is interesting to find that respondents of the both groups think of situation and attraction important besides ideology of cohousing. Development of attractive cohousing design could contribute significantly to residents' life satisfaction for long-run sustainability of the community.

Limitation of this study is that it is based on only quantitative research by questionnaire. Qualitative method such as in-depth interview with residents combined with mass survey could enrich interpretation of the research result. It must have been possible to describe hidden motivations behind that future-proof is required.

Though cohousing emerged in Europe, Asia, Australia and the USA during the past 20 years as an innovative housing form with a niche market, adoptions to date have been limited (Williams, 2008). As an implication of this study, in order to adopt cohousing model into other countries, diverse trials should be experimented. As Williams (2008) suggested, "grass-roots" approaches to the creation of cohousing communities are likely to result in the greatest number of adoptions in the future. Also administrative efforts are needed to facilitate cohousing model for marginal groups, for instance, singles/single-parent families/elderly households/ lowincome families to give advantages of cohousing characteristic. Cohousing could contribute to elevate marginal group's quality of life. Cohousing-like model based on collaborative network, or fictive kin in the community could facilitate the goal of selfsufficiency (Hasell \& Scanzoni, 2000). Therefore, to implement cohousing model into other countries, it needs to experiment with the notion of transplanting selected cohousing principles to a public housing development. 
As a suggestion, to facilitate cohousing model in Korea, administrative efforts are needed for the marginal group first. For instance, when public housing estate is developed, a few cohousing models could be experimented among many of other conventional housing. Through experience of cohousing life, people can try to make cohousing development on their own by grass-root approach.

\section{REFERENCES}

Ambrose, I. (1993), Etablering af seniorbofællesskaber, Erfaringer fratre projekter i Odense, Statens Byggeforskningsinstitut, København, Denmark.

Choi , M.R. \& Park, K.C. (1996). A Study on the Estimated Residential Mobility in Local Cities. Journal of the Architectural Institute of Korea. 12(11), 3-14

Choi, J. S. (2004). Evaluation of Community Planning and Life of Senior Cohousing Projects in Northern European Countries. European Planning Studies, 12(8), 1189-1216.

Choi, J.S. (2006). Preference of Common Spaces and Shared Activities in Senior Cohousing Community by Korean 50s, Proceedings of ENHR International Conference 2006, Urban Planning Institute of the Republic Of Slovenia. Ljubljana, Slovenia.

Choi, J.S. \& Cho, J.S. (2006). Differences between Male and Female in Moving Motivation and Life Satisfaction of Senior Cohousing Residents in Scandinavia. Journal of the Korean Home Management Association, 24(1), 117-128

Choi, J. S. \& Paulsson, J. (2006), Planning and Implementation of Scandinavian Senior Cohousing Projects, Seoul, Korea: Jipmundang Publishing Co.

Choi, J. S., \& Paulsson, J. (2011), Evaluation of Common Activity and Life in Swedish Cohousing Units, International Journal of Human Ecology 12(2), 133-146.

FIC(2007). Community Directory (2007). Routledge. USA.

Findlay, R.A. \& Morris, E.W. (1976). Social Determinents of the Design of Housing for the Elderly, Proceedings of the Annual Conference of the Environmental Design Research Association, Vancouver, 25-29.

Glass, A. P. (2009). Aging in a Community of Mutual Support: The Emergence of an Elder Intentional Cohousing Community in the United States, Journal of Housing for the Elderly, 23.283-303

Hasell, M.J., Scanzoni, J. (2000). Cohousing in HUD housing problems and prospects. Journal of Architectural and Planning Research, 17 (2), 133-145.

Im, K.H. \& Baek, S.J.(2011). A Study on Residential Mobility of Baby Boomers in Korea, Proceedings of Annual Conference of Korean Association for Housing Policy Studies . 1-10.

Jensen, S.P. (1994). Summary and Conclusion of the Conference on Cohousing for Senior Citizens in Europe, BiC, Copenhagen, Denmark. 8-13.

Kim,H.Y., Lee, Y.S. \& Yoon, H.K.(2010). The Study on Housing Characteristics Preferred by Baby Boomer After Retirement, Focusing on Apartment's Residents of Gangnam Region in Seoul. Journal of the Korean Housing Association. 21(5). 83-92.

Lietaert, M. (2010). Cohousing's relevance to degrowth theories, Journal of Cleaner Production, 18 (6), 576-580.

Marcus, C.C. (2000). Site planning, building design and a sense of community: An analysis of six cohousing schemes in Denmark, Sweden, and the Netherlands. Journal of Architectural and Planning Research, 17 (2). 146-163. Meeks, C.B. (1980). Housing. Prentice Hall Inc. USA.

Morris, E. W. \& Winter, M. (1978). Housing, Family and Society. John Wiley and Sons. New York, USA.

Nelson, L.M. \& Winter, M. (1975). Life Disruption, Independence, Satisfaction and the Consideration of Moving, The Gerontologist 15. 23-35.

Pedersen , M. (1999). Seniorbofælleskaber hvorfor og, Bolitrivsel i Centrum. København, Denmark.

SBI (1987). Cohousing Communities, Collection of Examples. Danish Building Research Institute, SBI-report 187.

Seo, W.S. \& Yoon, E.Y. (2011). Decision Factors on Residential Environment on Housing Mobility Intentions; Policy Implication in Korea through the Case of USA. Housing Studies Review 19(2). 151-170.

Tchoukaleyska, R. (2011). Co-housing childhoods: parents' mediation of urban risk through participation in intentional communities, Children's Georgaphies, 9(2). 235-246.

Toker, Z. (2010). New housing for new households: Comparing cohousing and new urbanist developments with women in mind. Journal of Architectural and Planning Research, 27 (4). 325-339.

Yang, S.W. \& Kim, M.J.(2011), A Comparative Study of Residential Mobility between Home-owning Households and Renting Households. Journal of Korean Home Management Association , 29(3). 13-22.

Yang, L.a , Zhou, J.a , Yan, X.b (2010). Environmental Strategies Analysis of Cohousing Based on Ecological Footprint. Proceedings of 2010 International Conference on Mechanic Automation and Control Engineering, MACE 2010, 4314-4317.

Vestbro, D. U. (1997). Collective Housing in Scandinaviahow feminism revised a modernist experiment. Journal of Architectural and Planning Research, 14(4), 329-342.

Williams, J. (2008). Predicting an American future for cohousing, Futures, 40 (3), 268-286.

Zhang, R., Lv, Y.H. (2011). A new living concept based on lowimpact strategy - The sustainability of cohousing community, Advanced Materials Research, 224, 220-223.

www.cohousing.org

www.kollektivhus.nu

(Received January 6, 2013/Accepted April 25, 2013) 